\title{
流域全体の土砂動態モデルに関する基礎的検討 FUNDAMENTAL EXAMINATION ON THE SYNTHETIC SEDIMENT ROUTING MODEL IN A WHOLE RIVER SYSTEM
}

\author{
砂田憲吾 ${ }^{1} \cdot$ 小松勝彦 ${ }^{2} \cdot$ 小林 弘 $^{2}$ \\ Kengo SUNADA, Katsuhiko KOMATSU and Hiromu KOBAYASHI \\ ${ }^{1}$ 正会員 工博 山梨大学教授 工学部土木環境工学科 （广400-8511 甲府市武田 4-3-11） \\ ${ }^{2}$ 学生会員 山梨大学大学院工学研究科（广400-8511 甲府市武田 4-3-11)
}

\begin{abstract}
It is required to develop an appropriate sediment routing model for describing behavior of sedimentation in a whole river system. This research deals with a synthetic sediment routing model based on DEM(Digital Elevation Models). This kind of model has several subjects to be examined from the viewpoints on model construction such as computational time interval, tuning hydraulic parameters, effects of computational mesh scale on the results, pseudo channel network made from DEM and so on. Authors have hitherto been examined some of the subjects mentioned above in the mountainous Hayakawa River basin $\left(509 \mathrm{~km}^{2}\right)$. In order to apply the model to larger river basin, the Fujikawa River basin $\left(3,571 \mathrm{~km}^{2}\right)$, a new method of automatical tracing of the channel network is adopted. In this paper, difference of channel networks between the conventional method and the new one is examined, and reasonable way of smoothing river bed as an initial situation is searched. The results of some cases of simulation on sedimentation in the basin is also discussed.
\end{abstract}

Key Words : sediment routing model, DEM, channel network, river bed variation

\section{1. はじめに}

今日，河川の計画や環境管理が，限定的な区間を対象 としたものから, 流域·水系を視点において考えられるよ うなってきている.すすなお，流域全体の水循環, 物質 循環の理解の下に水質や生態系のあり方も考虑に入れた 総合的な河川・流域の管理がめざされる時がきている. そ の際, 土砂の流送や堆積に焦点をあてて考えれば, 水源. 溪流から河川, 河口・海岸までを含んだいわゆる総合土砂 管理が目標とされることになる.

いま, 流域における土砂の生産, 供給, 侵食・洗据, 流下, 堆積およびそれらの結果生ずる河床の時間的変動 過程全体を土砂動態と呼ぶことにする.このとき, 流域 の土砂動熊の把握には当面二つの方向が考えられる. 第 一の方法は現地資料"をもとに空間的・時間的に集約し ていわば集中システムを考え, それらを多数組み合わせ て全体を構成する方法2) である. この方法は経験・実績 に基づく従来の主な手法に相当するが, 降雨などの外力 の変化に伴亏将来の予測や流域の条件の変更を考慮しに くい.これに対する第二の方法として，分布システムの 考え方に基づいて, 地形や表層地質の空間的な分布を考 慮して降雨·流量変化に応じた流域全体の土砂の流送·堆
積を調べる方法3,4, 4, 5, 6, 7)である．細部でのモデルの蕨密 さを若干㩘牲にすれば，物理的な観点から流域のいわゆ る「土砂動態」が記述される唯一の方法と考えられる。

筆者らは後者の立場に立って, これまでに水系土砂動 態のモデル化について検討を重ねてきだ,4,8). 流域客観情報としての数值地形を用いることにより, ま ずはどの流域にも適用可能であるが，対象とする現地の 状況に合わせてモデルの精密化が着実に期待できると考 えている. 土砂の流送と収支に基づく方法ではあるが, いくつかの課題もある. これまでに, 数值地形のメッシ ユの大きさが計算結果に及ぼす影響，計算時間間隔，パ ラメータの設定やそれらの計算結果への感度, などにつ いて検討してきた. その結果，細かな配慮で設定された 早川流域 $\left(\right.$ 約 $\left.500 \mathrm{~km}^{2}\right)$ の擬河道網によれば, 実測值にほ ぼ対応する河床変動の再現が可能で, モデル構成の大枠 が得られている.

本論文では，これまで対象としてきた山地河川流域か ら流域を拡大して河口までを持つ富士川全流域（約 3, 600 $\left.\mathrm{km}^{2}\right)$ を対象とする. 従来の早川流域では本川・主 要支川では河床高を地形図より与えていたが，富士川流 域ではもはやそうしたマニュアルでの河道の調整は困難 となる. ここでは, 自動的に生成される別のタイプの河 道網を用いての計算方法を進めるための検討を行った. 


\section{2. 地形図補正型擬河道網による早川水系における

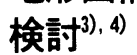

\section{（1）モデルの基本構成}

当初モデル適用の対象としたのは富士川支川早川水系 (流域面積509. $1 \mathrm{~km}^{2}$ )である。この流域では, 系魚川-静岡 構造線が通り，脆弱な地質に伴う多数の崩壊地が分布し， 多量の土砂を流出している。昭和57年における流出土砂

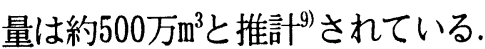

流域内の各種地形情報を考慮するために国土数值情報 の標高データ (KS-110-1)を用い，落水線理論により擬河 道網を作成する（後出する図-6左に早川の擬河道網を示 す）。この際，早川本川，主要支川についてはメッシュ 点位置・標高を，地形図を用いてマニュアルで入力して いる. 以後これを地形図補正型擬河道網とする. 擬河道は 幅広矩形断面とし流域面積 $A\left(\mathrm{~km}^{2}\right)$ （各格子点での集水面 積)より推定河幅 $B(\mathrm{~m})$ を次式(10)で与える.

$$
B=B_{0} A^{k}
$$

ただし， $B_{0}, k$ はパラメータで, 早川本川下流域におけ る実河道幅との比較から $B_{0}=10.0, k=0.5$ とした. 顕著な 河床変動は日雨量 $100 \mathrm{~mm}$ 以上の降雨に対して起こるとし, その期間の降雨強度(時間単位)を抽出して流出関数法に より流量を算定し区間等流の近似により掃流力等を計算 する. 各メッシュ点付近の単位面積あたりの土砂生産量 $V\left(\mathrm{~m}^{3} / \mathrm{km}^{2} / \mathrm{hr}\right)$ は現地資料 ${ }^{11)}$ をに次式で与える.

$$
V=\beta \theta^{0.5} r^{2}
$$

ここに, $r:$ 降雨強度 $(\mathrm{mm} / \mathrm{hr}), \theta:$ 斜面勾配, $\beta$ :土 砂生産の程度を表す係数であり, 早川流域での計算結果 から逆推定した $\beta=0.01$ を用いた. 土砂粒径 $d(\mathrm{~cm})$ は区間 ごとの一様砂として扱い, Sternberg-物部の式を基に次 式で与える.

$$
d=d_{0} \theta^{2 / 3}
$$

ただし $d_{0}$ はパラメータで実測值をもとに $d_{0}=18.3$ とした.

土砂輸送にはBrown型の流砂量式を用い, 各河道区間格 子点で連続式(4)により河床変動高を求める.

$$
\Delta z=\frac{Q_{\text {Bin }}-Q_{\text {Bout }}}{A_{t}(1-\lambda)} \Delta t
$$

ここに, $Q_{B i n}$ : 単位時間当たりの流入土砂量 $\left(\mathrm{m}^{3} / \mathrm{s}\right)$, $Q_{\text {Bout }}$ : 単位洔間当たりの流出上砂量 $\left(\mathrm{m}^{3} / \mathrm{s}\right), A_{t}$ : 土砂堆 積面積 $\left(\mathrm{km}^{2}\right), \lambda$ : 河床空隙率である. また流送土砂量に ついては, 支川下流や本川では平衡流砂量として扱って いるが，上流域では岩盤等の影響を考慮して流送土砂を 制限している.

他，モデルの詳細については文献3), 4)を参照されたい.

\section{（2）河床变動計算結果之妥当性}

これまで，筆者らにより早川水系へ土砂動態モデルが

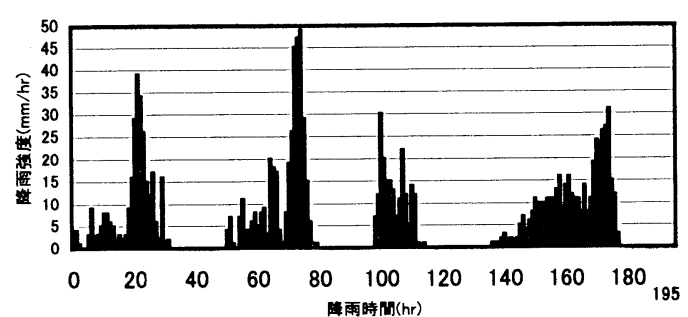

図-1＼cjkstart降雨強度時系列図(s. 56. 3 s. 58. 2)

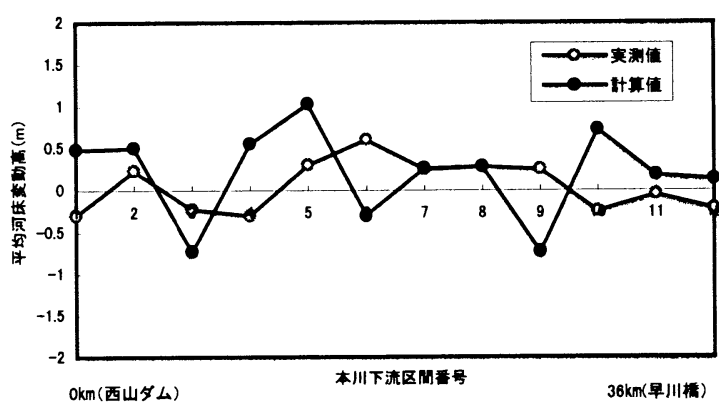

図-2＼cjkstart河床変動測量結果との比較

適用され，いくつかの検討が行われてきた. 対象期間は 昭和 56 年 3 月から昭和 58 年 2 月であり, その間の日雨量 $100 \mathrm{~mm}$ 越える降雨時系列は图-1に示される. 図-2は対象 期間における早川水系内の西山ダムから早川橋までの早 川河床変動測量結果と250mメッシュの河床変動計算結果 (河床変動計算結果とは, 図-1に提示した降雨後の計算 河床高と初期河床高の差である）との比較を表したもの である゙). 計算值と実測值には1区間のずれはあるものの, 河床変動絶対値・区間ごとの変動パターンを判断基準に 考えれば概ね妥当性が得られる. また, 河道網の要素ス ケールの検討によれば, 局地的な点を除けばモデル化に おける $250 \mathrm{~m} ・ 500 \mathrm{~m}$ のッシュスケールの影響は小さいと

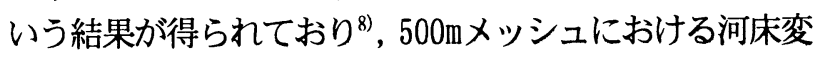
動計算結果の妥当性も説明できる.

さらに,これまでの研究礼により, 支川単位毎の早川流 域の実測による流出土砂量との比較を行い, 流域の内部 および流域全体での間接的な妥当性が得られている.

\section{3. 富士川水系自動作成型擬河道網と問題点}

地形図補正型擬河道網でモデル化した早川水系から, 富 士川水系全域 (流域面積 $3571.2 \mathrm{~km}^{2}$ ) に対象を拡大し, 擬河 道網を作成するにあたり, デー夕量の増加に伴ういくつか の問題が生じる. 例えば落水線の行き場を失った察地など のエラーに関して,これまでのように地形図を用いた手入 力での修正では非常に煩雑になる. そこで, 竹内 ${ }^{22}$ らの提 案している，DEMのみを用いて擬河道網を自動作成する， いわゆる富士川水系自動作成型擬河道網（図-3右）を用い て検討を行う. 図-3左に示した早川水系地形図補正型擬河 


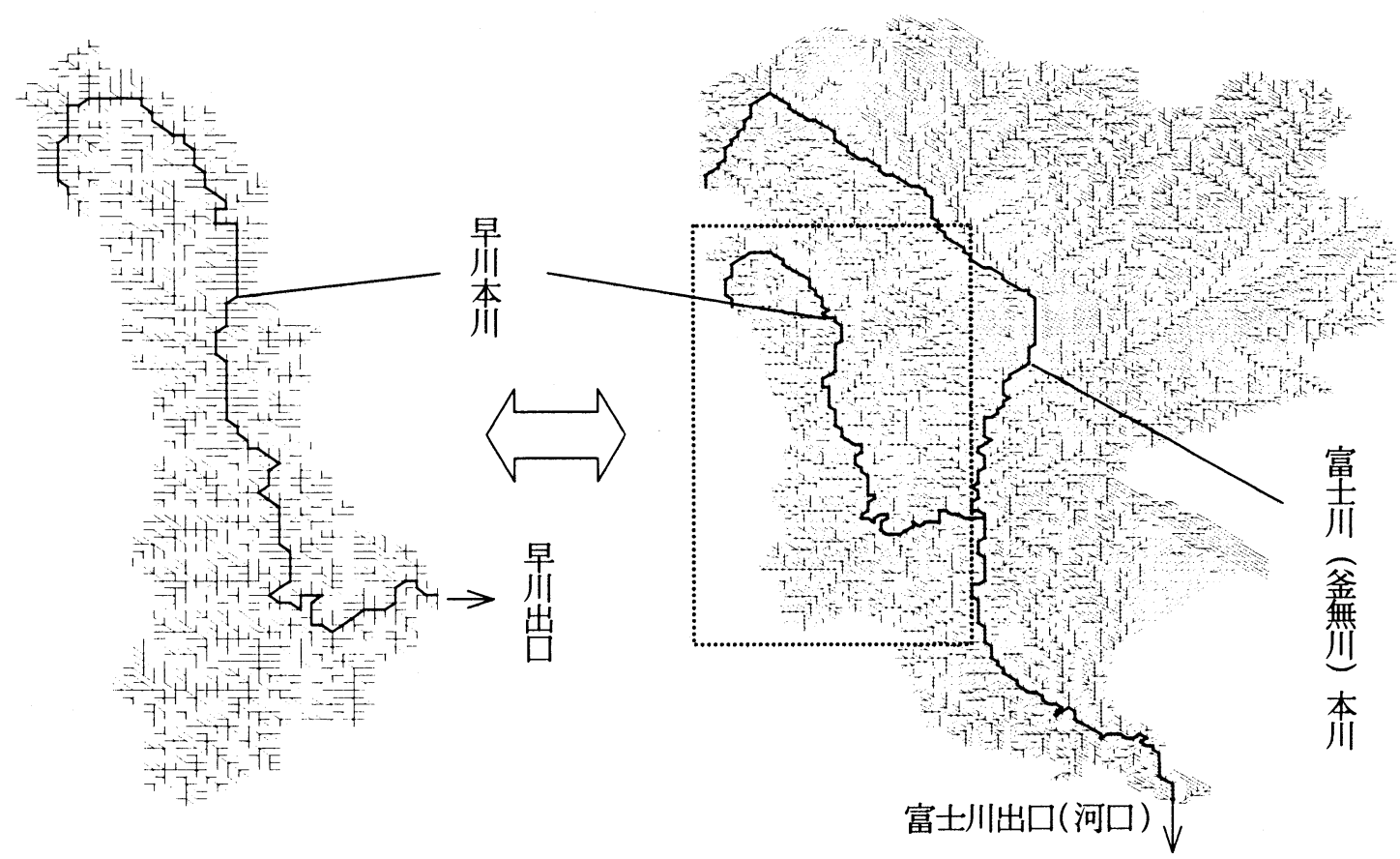

図-3 対象擬河道網（左: 早川水系地形図補正型, 右 : 富士川水系自動作成型）

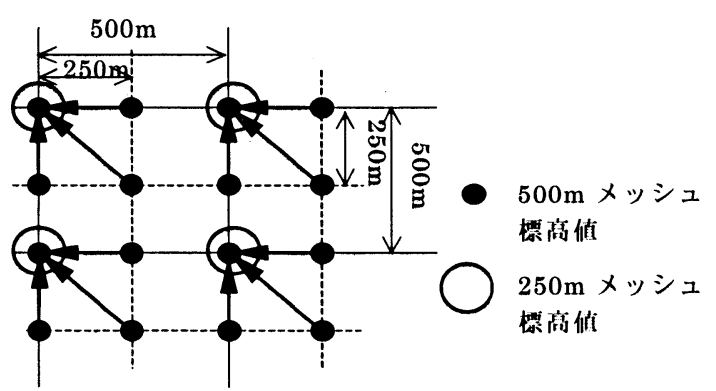

図-4 スケールアップの概要

道網とは以下の点が主に異なる.

\section{（1）擬河道網の変更点}

a）スケールアップ手法

$250 \mathrm{~m}$ メシュの擬河道網を, $500 \mathrm{~m}$ メシュにスケール アップした擬河道網をここでの基本モデルとする. さら に, $250 \mathrm{~m}$ メシュ間隔に並んでいる標高データを直接 500m間隔で抽出するこれまで用いてきたスケールアップ 手法に対して, 図-4に示すように250mメッシュの標高値4 点を平均した值を $500 \mathrm{~m}$ メッシュの標高值として抽出する 平均型のスケールアップ手法を用いている.

b）実河川情報

落水線理論に基づき擬河道網を算出する際，500mメッ シュの標高データと落水線計算だけで流域地形を等価に 表現するのは難しい。そここで, 前述のように, 地形図補 正型では2万5千分の1の地形図を用いて, 実河川の位置・ 標高を最も近いメッシュ点に近似し，流域地形の再現性 の向上に努めた. しかしながら, 流域の桩大に伴い地形 図の利用に限界が生じることから，ここでは国土数值情 報の流路位置データ（KS-272）を用い，500mメッシュの

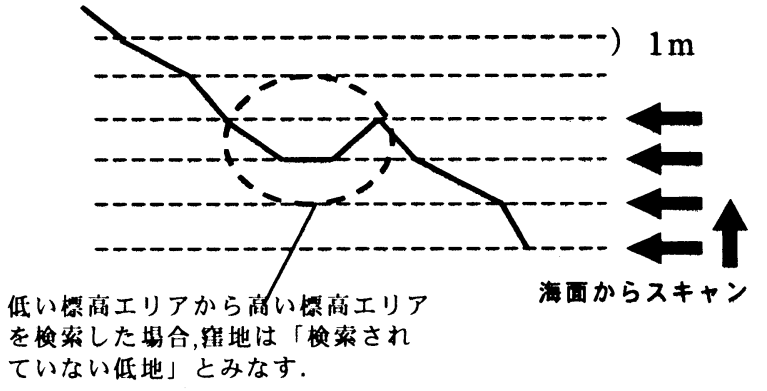

図-5 複数点で構成される篞地の処理

河川流下方向データを作成し，これを基に富士川および 早川·笛吹川の流路方向を定義した. 尚, 同時に記録され ている標高值は, 擬河道網との対応上の問題から使用で きず, 実河川部分における標高值には標高テータ (KS-110-1)の值をそのまま使用した.

c）䆶地処理方法

標高データの精度の問題で生じるとされる単点の䆶 地は, 周囲点の標高値が自点よりも高いために起こる ため, 自点の標高值を周囲8点の標高値之同値に修正す る. 一方複数点で構成される䇠地処理は, 単点でおこ る窪地の処理方法と同じには扱えない. 対象流域を含 む標高データ全域を, 最低標高値レベル（河口・海面） から最高標高值まで1mごとに検索していき，图-5に示 すように, 連続して検索されない内陸の低い点を窪地 と見なし $1 \mathrm{~m}$ の標高増量処理を行う. ただし, データに よっては大量に標高を修正（增量）してしまい，特に 富士川下流域では川筋が一部再現されず河筋標高がも りあがってしまうという問題が生じる. そこで, 河川情 報の川筋を上流から下流へ1メッシュずつ順に巡ってい き, 自点から見た下流点が自点より高い場合, 自点と同 


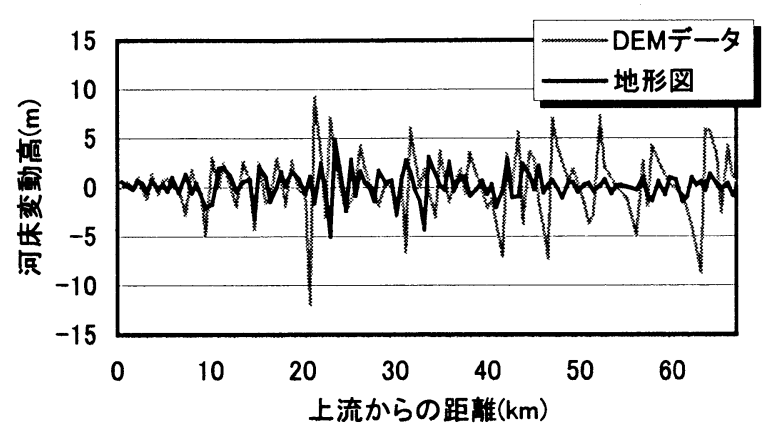

図-6＼cjkstart早川本川河床変動図

值まで標高を下げることで河道の調整を行っている.

\section{（2）河床変動計算結果と問題点}

この富士川水系自動作成型擬河道網を用いて早川本 川において河床変動計算を行った. 2-(1)で示すように, 早川水系で先に提案された土砂動態モデルを適用し, 図 -1に示した降雨強度を与えて計算している. 自動作成型 の富士川水系擬河道網と, 地形図補正型の早川水系擬河 道網, 両者の早川本川における河床変動計算結果を比較 したものを図-6に示す. 上流においては比較的同様な傾 向を示したが, 中流から下流にかけては変動が極端に強 調される傾向が見られた. この大きな要因と考えられる, 擬河道網の初期設定の差異について検討してみた. 図一7 は图-6で違いの著しかった早川本川下流区間の初期設定 段階における河床縱断図を示したものである. 自動作成 型擬河道網は, 地形図補正型に比べ河床縦断の凹凸が大 きくなっており, 特に下流域においてはその傾向が顕著 になっている. これより，図一におおける河床変動計算結 果の違いは，河床勾配の初期設定に大きな原因があると 考えられる. したがって, 河床変動計算結果の精度を上 げようとすれば，富十川水系自動作成型擬河道網におけ る初期河道を新たに調整する必要が出てくる.

\section{4. 初期擬河道網の設定}

DEMのみを用いた自動作成型擬河道網により流域地形 を表現することは非常に困難である. しかしながら, 流 域の拡大に伴い大量のデータを扱う関係上, 効率的かつ 大枠での土砂動態把握が必要となる. その意味では自動 作成型擬河道網の利用が効果的であるが，精度を上げる ための処理が必要になる. そこで自動作成型擬河道網の 初期河床絽断形状を, 地形図補正型擬河道網の河床縦断 形状に近づけるために2つの方法を用いて検討した.

\section{（1）先行流出法}

本河床変動計算は, 時間経過に伴って徐々に河床が平 滑化されるという傾向がある. そこで富士川水系自動作 成型擬河道網に一定降雨強度の雨を 3000 時間発生させ, 早川本川河床の平滑化を行った，その平滑化された早川

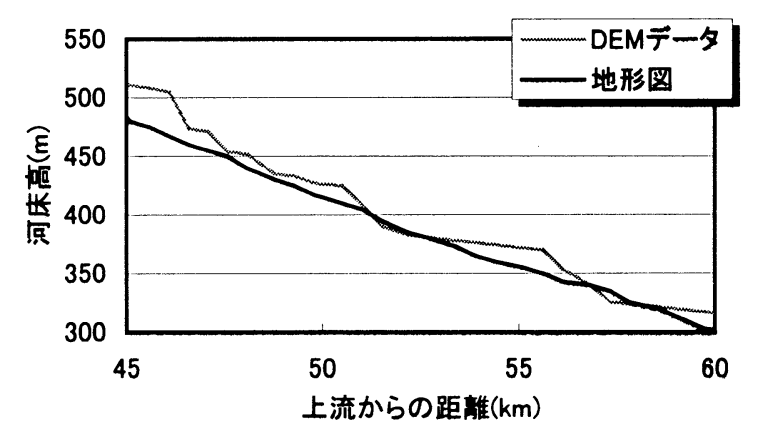

図-7＼cjkstart早川本川河床高緥断面図

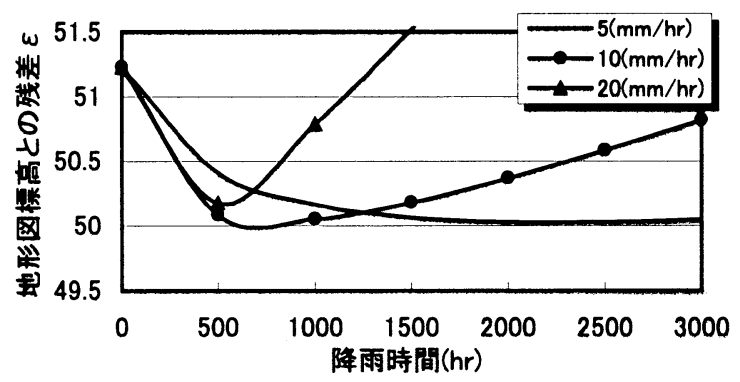

図-8 流出時間と残差の関係

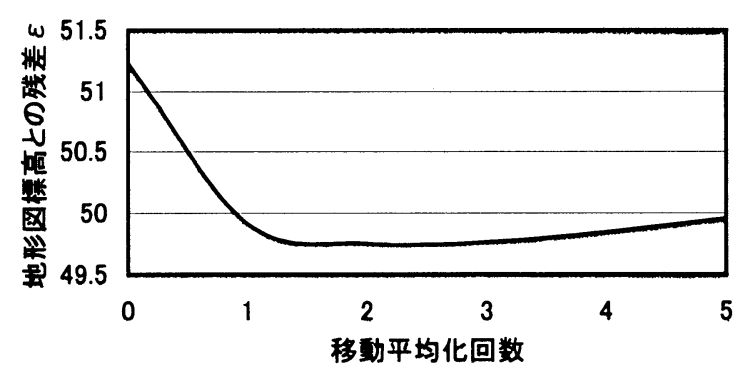

图-9 平滑化回数と残差の関係

本川の河床勾配を新たな初期河床勾配とみなす.その際 各降雨強度における最も平滑化が進んだ時間を算出し， その降雨強度における最適な本川河床部の平滑化時間と 判断した. その算出方法は, 地形図補正型擬河道網の早川 本川部の標高と, 自動作成型擬河道網において各時間で 平滑化された早川本川部の標高との残差 $\varepsilon$ を(5) 式より 求め, その適合度の判定を行った. 実際にはその中で残差 $\varepsilon$ の值が急激に減少した時間を最適な時間と判断した。

$$
\varepsilon=\sum\left(Z_{\mathrm{i}}-Z_{\mathrm{i} 0}\right)^{2} / \mathrm{n}
$$

ここに $\varepsilon:$ 残差 $\left(\mathrm{m}^{2}\right), Z_{\mathrm{i}}$ : 各時間における平滑化された 早川本川部各地点の標高 (m) $z_{\mathrm{i} 0}$ : 地形図から読みとった 早川本川部各地点の標高 $(\mathrm{m}), \mathrm{n}$ : 早川本川部分における標 高データの数を示し, その数は119個である.ここでは, 3 種類の降雨強度における先行流出を行い, 降雨時間と残 差 $\varepsilon$ の関係を調べた. その結果を図-8 に示す. 図か ら, $10(\mathrm{~mm} / \mathrm{hr})$ の降雨強度では 500 時間程度のシミュレー ションで最も早川本川の河床が平滑化されたと考えられ る. 


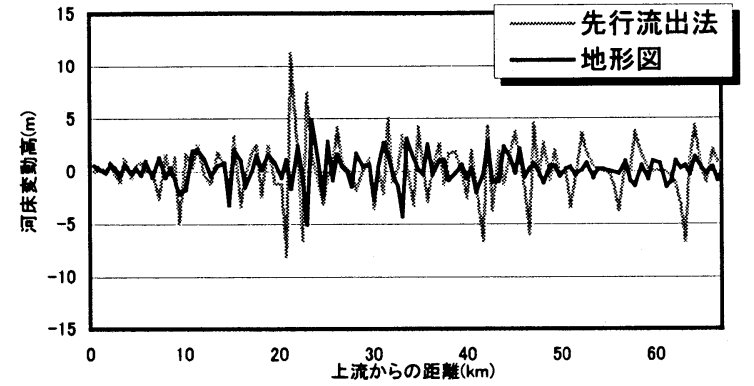

図-10 早川本川河床変動図 (先行流出法)

\section{（2）地形平滑化法}

次に, 自動作成型擬河道網の早川本川における各河床 高の移動平均計算を(6) 式により行い平滑化を行った.

$$
Z_{\mathrm{mi}}=\left(Z_{\mathrm{i}+1}+2 Z_{\mathrm{i}}+Z_{\mathrm{i}-1}\right) / 4
$$

以下，（1）における先行流出法と同様に，平滑化された 早川における河床勾配を初期值とする.

ここに $Z_{\mathrm{ni}}$ : 移動平均により新たに算出された早川の標 高 $(\mathrm{m}), z_{\mathrm{i}}$ : 平均化の対象となる地点の本川部の標高 (m), $z_{i+1}, Z_{i-1}$ : 前後の噤高 (m) である. 以下，(1) と同様に 残差 $\varepsilon$ をとり, その值が急激に減少している箅所の回数 を平滑化に最適な移動平均回数とした．この地形平滑化 法における, 移動平均回数と残差 $\varepsilon$ の関係図を図 -9 に示 す.

\section{（3）早川本川河床における平滑化の考察}

先行流出法において, 早川本川河床部を平滑化するの に最適な時間は, 降雨強度 $5(\mathrm{~mm} / \mathrm{hr})$ の時は約 800 時 間, $10(\mathrm{~mm} / \mathrm{hr})$ の時は約 550 時間, $20(\mathrm{~mm} / \mathrm{hr})$ の時は約500時 間であると判断できた. また，地形平滑化法においては, 移動平均回数2回が平滑化に最適な回数と判断できた.こ こで, 各方法における最適降雨時間 (降雨強度 $10(\mathrm{~mm} / \mathrm{hr}$ ) を使用する）・移動平均回数で平滑化した早川本川河床 勾配を初期値として，図-1の降雨強度を模擬的に与えて 河床変動計算を行った. 地形図補正型擬河道網における 計算結果との比較したものをそれぞれ図-10，図-11に示 した.

先行流出法(図-10)においては 上流部から中流部にか けて, 河床変動の傾向が比較的類似しているものの, 図 -6に比べて局部的に変動高の幅が大きくなる場所も見ら れ，顕著な改善は得られなかった. しかしながら，全体 的な距離方向の変動の傾向が類似している点は興味深い.

地形平滑化法（図-11）においては，上流部から中流部 にかけて変動パターンが, 特に変動高の幅が非常に類似 してきており，下流域に行くにしたがって，その傾向は 小さくなっている. また, 変動高の幅が全体的に均一に なる傾向が，この手法の特徵であるといえる. 取り扱い の簡便さから，地形平滑化法も有効な方法と考えられる.

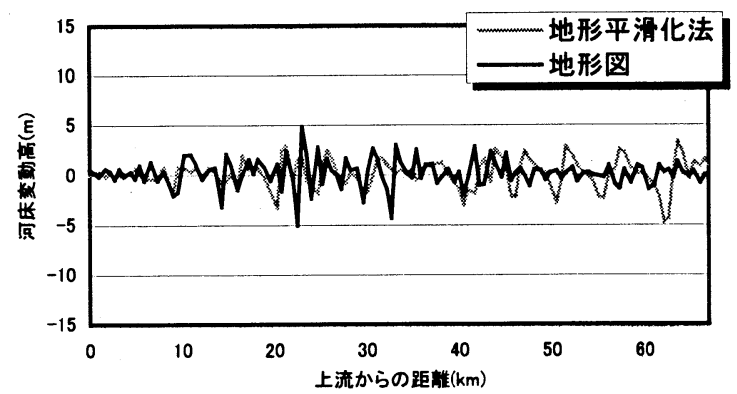

図-11早川本川河床変動図 (地形平滑化法)

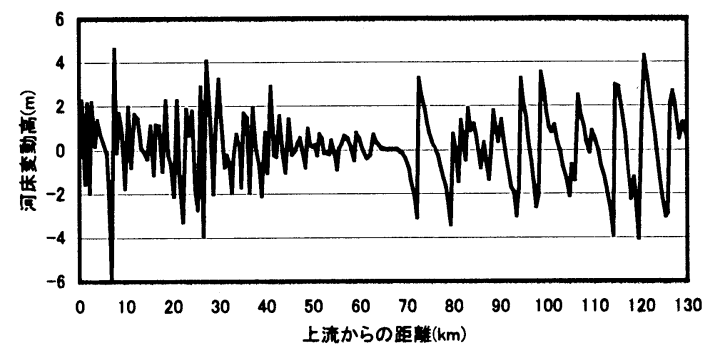

図-12 富士川本川河床変動図 (平滑化行わず)

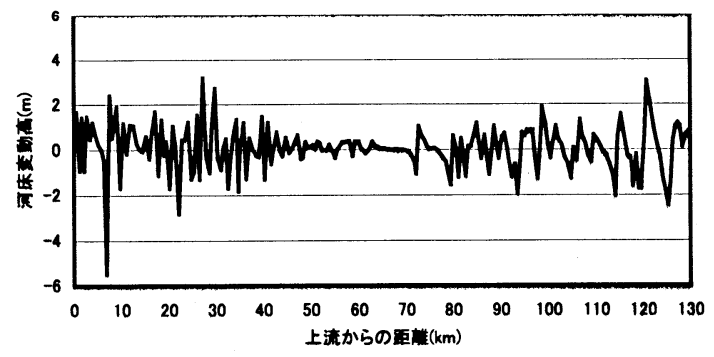

図-13 富士川本川河床変動図 (先行流出法)

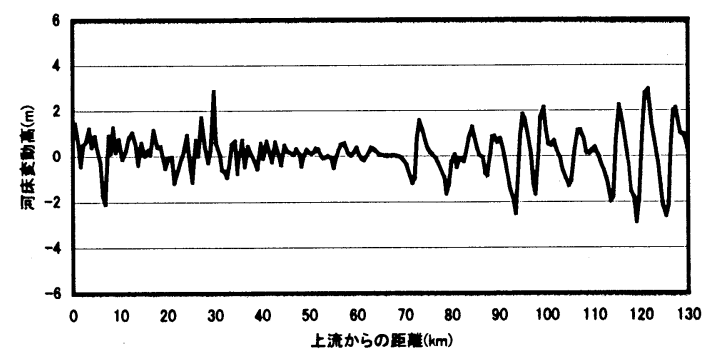

図-14富士川本川河床変動図 (地形平滑化法)

2つの平滑化処理に共通している点は, 上流域から中流 域にかけて処理の効果が現れているものの, 下流域にか けてはそれが小さくなる点である.これより, 河床勾配 が緩やかな下流域では正確な流域の地形特性をDEMデー 夕のみで表現するのが困難となるものと考えられ，より 下流域ではより精度の高い河床標高值が必要とされる.

\section{5. 富士川流域への適用}




\section{（1）デー夕調整とその方法}

4-(3)により判断した先行流出法・地形平滑化法におけ る最適な降雨時間(降雨強度 $10(\mathrm{~mm} / \mathrm{hr})$ を使用する) ・移動 平均回数を富士川流域に適用し平滑化を行う. また平滑 化処理により, 新たに生じた窪地については, その個所の 標高を $10(\mathrm{~cm})$ 底上げすることで解消した. 以上の処理を 行った富士川水系擬河道網を用いて, 図一1の降雨強度を 模擬的に与え河床変動計算を行った.

\section{（2）計算結果之考察}

平滑化を行う前の粗雑な河床部のままで行った富士川 本川部分の河床変動図を図-12に, 先行流出法によって平 滑化された富士川本川部の河床変動図を図-13に,そして 地形平滑化法によって平滑化された富士川本川部の河床 変動図を図-14に示す．3つの計算結果とも50～60km地点 で河床変動の小さな区間が認められる. 実際にはこの地 点は甲府盆地南部にあたり, 河床変動の小さいところで もある. これらのシミュレーションでもこのことが再現 されている.

図-12における河床変動高の幅は, 平滑化した2つのシ ミュレーション結果(図-13,14) と比べると約2倍近くあ る.これは河川における河床変動が河床勾配に大きく左 右されているからである. また4-(3)において, 地形図補 正型擬河道網における早川本川の河床変動図との比較を しているが，両者とも上流域から中流域までは変動パ夕 ーンおよび変動高の幅が比較的類似していたのに対し， 下流域にかけてはその変動が大きく異なっていた. この ことは 2つの方法で平滑化された富士川本川の河床変動 図からも同様なことが認められた. 実際にその両者の結 果である 図-13と図-14を比較してみると, 上流部から中 流部にかけては両者ともある程度近似しており, 流域の 地形条件を反映した富士川本川における河床変動の結果 を得ることができたと考えられる. それに対し，下流域 の河床変動の結果においては, 早川流域の結果と同様, 河 床変動幅が大きく, 精度の高い結果が得ることができた とは必ずしも言えない.

実際に地形図等から読みとった富士川本川部の河床標 高を初期值として河床変動計算を行い, 今回の結果と比 較する必要性はあるが，流域全体における擬河道網を用 いて河床変動を算出する際, 下流域のデー夕は上流域の データより適切なデータが必要とされるようである.

\section{6. おわりに}

水系全体の土砂管理と計画のために，さらにはより広 大な流域や河道資料の不十分な流域での土砂動態把握の 可能性を得るために, 自動作成型擬河道網を用いていく つか検討を行い, 以下の結論を得た 1) 河床変動計算結果 の精度を高めようと考えるならば, 本川部における初期
河床勾配のより的確な見積もりが必要である. 2) 特に, 下流域における河川のデー夕は河床変動の算出結果の精 度を大きく左右する.

上中流域において河道調整による効果がみられること から, 流域全体での土砂動態把握に関して大枠ではある が可能性が開かれた. しかしながら，下流域における諸 データの合理的な組み込み手法, 実測データとの検証な ど課題も残されており, 今後検討していく予定である.

謝辞 : 本研究を遂行するに当たり, 山梨大学工学部土木 環境工学科の竹内邦良教授，石平博講師には，貴重な資 料を提供して頂きました. ここに記して謝意を表します.

参考文献

1）たとえば，建設省河川局・土木研究所 : 砂防河川の土砂動 態に関する研究 建設省. 技術研究会報告, pp. 525-565, 1979, pp. 641-678, 1980, pp. 563-582, 1981.

2）たとえば，高秀秀信・九津見生哲・藤沢 寛: 水系におけ る上砂動態について, 第27回水理諢演会論集 pp. 707-772, 1983.

3）砂田憲吾·長谷川登 : 国土数值情報に基づく山地河川水系 全体における土砂動態のモデル化の試み，土木学会論文集， No. 485/II-26, pp. 37-44, 1994.

4）砂田憲吾・塩沢みゆき・加藤克夫：大規模土砂生産による 流域水系河床変動の伝播特性について, 水工学論文集, Vol. 40 , pp. 843-848, 1996.

5）宝馨・上圾隆平・野ツ俣克彦：ブランタス川流域の土地被 覆分類亡土砂流出解析, 京都大学防災研究所年報 第42号, B-2, pp. 291-309, 1999.

6）松木 敬・江頭進治・上妻由拓: キネマティックウェーフ 法に基づく土砂流出予測, 土木学会第54回年次学術靔演会 講演概要集，pp. 442-443，1999.

7）市川 温・佐藤康弘・椎葉充腈・立川康人・宝馨 : 山地流 域における水・土砂動態モデルの構築, 京都大学防災研究 所年報，第42号，B-2，pp. 211-223，1999.

8）砂田憲吾・小松勝彦・柴田高教・杉浦信男 : 数值地形情報 に基づく水系土砂動態モデルの構成に関する検討, 水工学 論文集, Vol. 43, pp. 551-556, 1999.

9）建設省関東地方建設局富士川砂防工事事務所 : 昭和58年度 災害調查業務委託報告書, 1984.

10）睦 旻皎・小池俊雄・早川典生 : 分布形水文情報に対応す る流出モデルの開発，土木学会論文集，第411号／II-12, pp. 135-142, 1989.

11）橋本 明・板口哲夫・野島博欠：土砂移動モデルの作成に ついて, 第36回建設省技術研究会報告, pp. 855-860, 1982.

12）竹内邦良・石平 博・栗木美宜: 実河道網デー夕を用いた 擬河道網の自動作成法に関する研究，水文・水資源学会研 究発表会要旨集，pp. 188-189，1999.

(1999. 9. 30受付) 